\title{
Flow carbonylation of sterically hindered ortho-substituted iodoarenes
}

\author{
Carl J. Mallia ${ }^{1}$, Gary C. Walter ${ }^{2}$ and lan R. Baxendale ${ }^{* 1}$
}

\section{Full Research Paper}

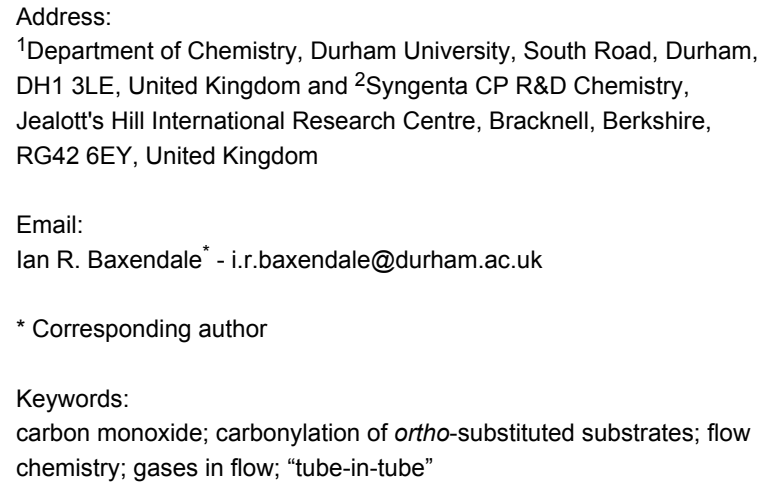

Beilstein J. Org. Chem. 2016, 12, 1503-1511.

doi:10.3762/bjoc. 12.147

Received: 05 May 2016

Accepted: 27 June 2016

Published: 19 July 2016

This article is part of the Thematic Series "Automated chemical synthesis".

Associate Editor: A. Kirschning

(C) 2016 Mallia et al.; licensee Beilstein-Institut.

License and terms: see end of document.

\begin{abstract}
The flow synthesis of ortho-substituted carboxylic acids, using carbon monoxide gas, has been studied for a number of substrates. The optimised conditions make use of a simple catalyst system compromising of triphenylphosphine as the ligand and palladium acetate as the pre-catalyst. Carbon monoxide was introduced via a reverse "tube-in-tube" flow reactor at elevated pressures to give yields of carboxylated products that are much higher than those obtained under normal batch conditions.
\end{abstract}

\section{Introduction}

Carbonylation reactions have received a great deal of attention both in batch as well as in flow (using plug/annular flow reactors [1-5] or "tube-in-tube" reactors [6-10]) and generally produce the desired products in good yields [11-14]. This is not the case though for the carbonylation of ortho-substituted substrates which are much more challenging as highlighted by the limited literature precedence [15-17]. However, these products are of considerable industrial importance, especially the amide and ester derivatives, which are commonly found in agrochemical active ingredients, for example tecloftalam, flutolanil, fluopyram and diflufenican. Likewise, in pharmaceutical compounds such as 2,4,5-trifluorobenzoic acid, which serve as a starting material for several antibacterial drugs such as ciprofloxacin $\left(\right.$ Cipro $\left.^{\mathrm{TM}}\right)$, norfloxacin $\left(\right.$ Noroxin $\left.^{\mathrm{TM}}\right)$ and pefloxacin (Peflacine $\left.{ }^{\mathrm{TM}}\right)$.

The low catalyst turnover frequency (T.O.F.) and poor yields associated with ortho-substituted transformations are attributed to the carbon monoxide coordination to the intermediate aryl transition metal (i.e., Pd) complex which is inhibited by sterics [15]. Following oxidative addition of the aryl halide, an associative mechanism for the complexation of carbon monoxide on the $\mathrm{d}^{8}$ square planar intermediate would occur prior to the key migratory insertion step. In the complex, the aryl group would 
be oriented perpendicularly to the plane to minimise steric interactions thus placing the ortho-substituent directly over an axial site (Figure 1). The ortho-substituent therefore acts as a steric buttress hindering the approach of the incoming carbon monoxide thus slowing down the rate of the reaction. An X-ray structure of trans-bromo(o-tolyl)bis(triphenylphosphine)palladium(II) complex was reported by Cross et al. (Figure 2) [18] The molecular structure of $\mathbf{1}$ comprises of a palladium atom with near perfect square planar geometry with a slight out of plane displacement of $\mathrm{Br}$ and $\mathrm{C}(1)$ where the $\mathrm{Br}-\mathrm{Pd}-\mathrm{C}(1)$ angle is $170.9^{\circ}$. As a whole, the molecule has approximate $C_{S}$ symmetry with the $\mathrm{PPh}_{3}$ ligands almost eclipsing each other if viewed along the $\mathrm{P}-\mathrm{Pd}-\mathrm{P}$ axis, with the tolyl group sandwiched between the two phenyl groups (Figure 2, structure B). Focusing on the tolyl group only, structure C (Figure 2) shows how the methyl of the tolyl group is placed straight over the axial position of the palladium. Structure D (Figure 2) is a top view of the crystal structure illustrating how the methyl group sits directly over the axial position of the palladium which would introduce steric effects inhibiting the $\mathrm{CO}$ coordination on the intermediate aryl complex.

As the carbonylation step becomes slower, the competing dehalogenation pathway becomes dominant resulting in overall

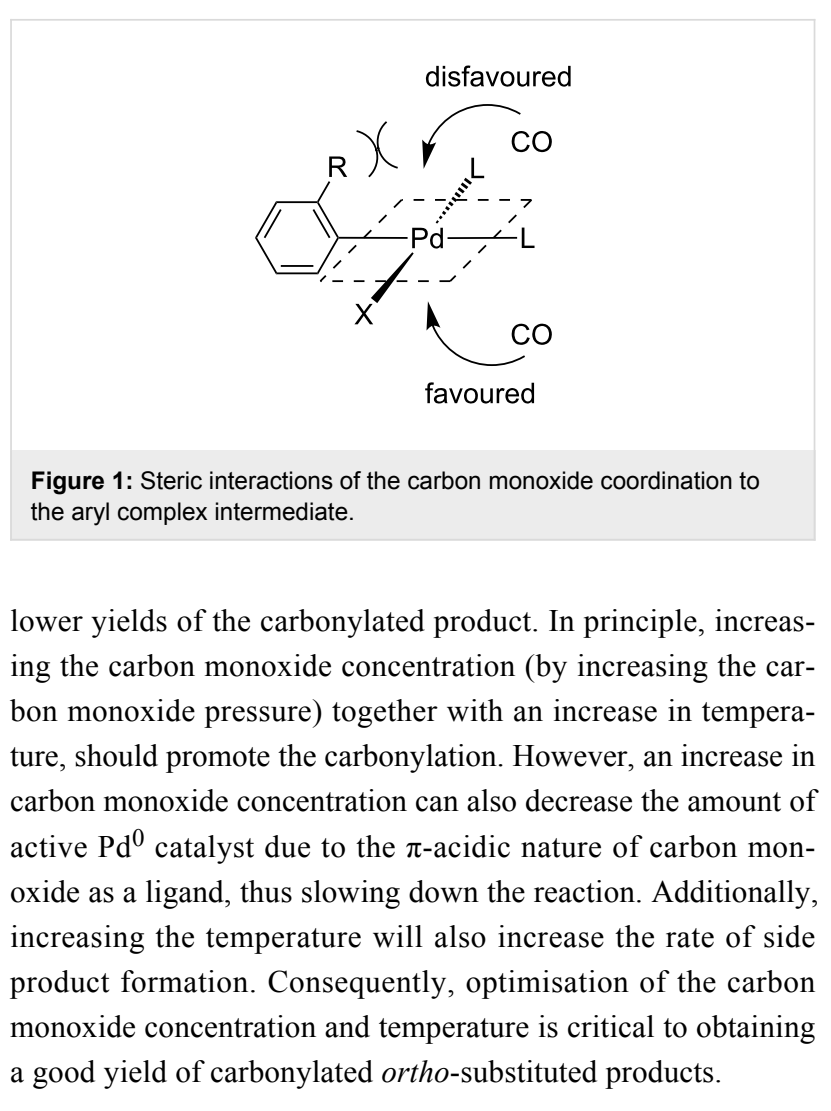

A)

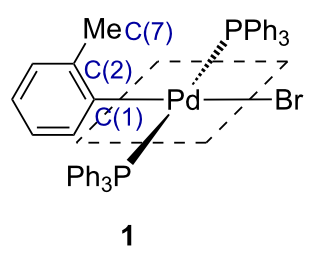

C)

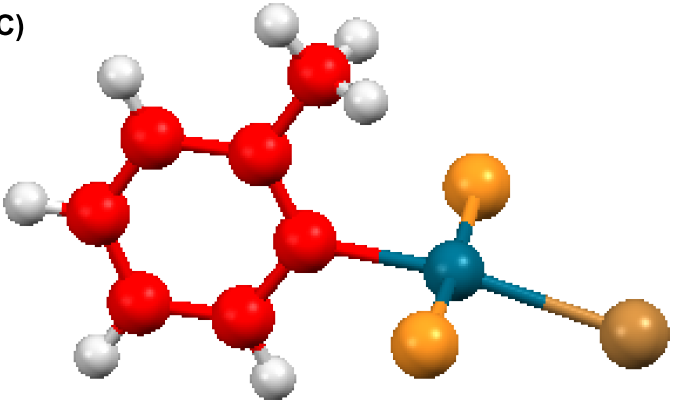

B)

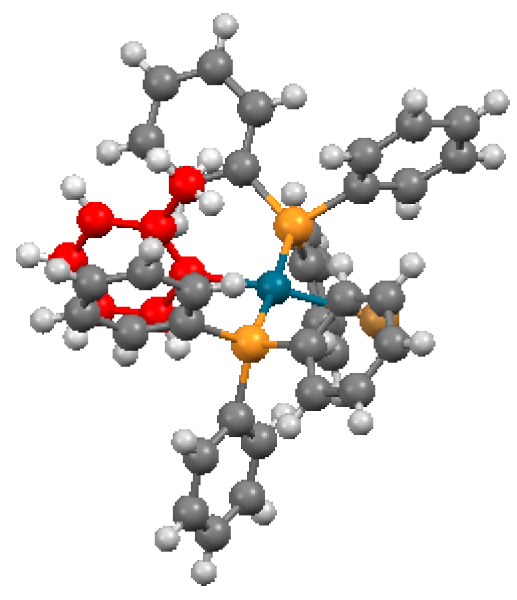

D)

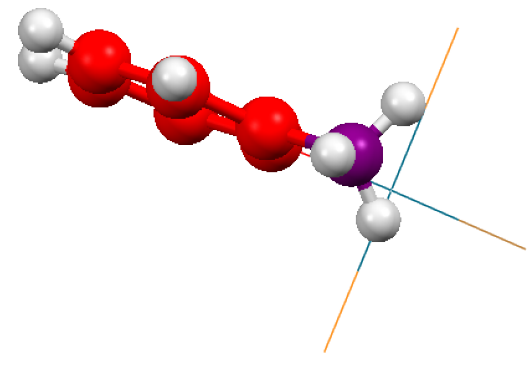

Figure 2: A) molecular structure of complex 1;B) ball and stick representation of X-ray structure; C) ball and stick representation of X-ray structure showing the tolyl group only; D) topside view of X-ray structure [18]. 


\section{Results and Discussion}

The application of flow chemistry $[19,20]$ has been shown to be beneficial for many reactions that involve gases [21-29]. The efficient mixing along with high heat and mass transfer that are achieved through the use of small dimensioned channels such as those found in flow reactors, allow for the use of a wider range of reaction conditions which are otherwise difficult or impossible to achieve. The interfacial mixing area is also an important characteristic when gases are involved as this is an essential factor determining the solubility of a gas in the liquid phase. The interfacial area is generally very small when traditional batch chemistry equipment is used such as round bottom flasks. This also becomes proportionally smaller when larger volume flasks are used as in scale up procedures making the mass transfer even less efficient. In contrast, high interfacial areas can be achieved in flow reactors especially microchannel reactors ( $a=3400-18000 \mathrm{~m}^{2} \mathrm{~m}^{-3}$ ) [30], which increases the mass transfer and thus helps solubilise the gases in the liquid phase.

In our work a reverse "tube-in-tube" reactor [31-33] was used to deliver the carbon monoxide to the reaction (Figure 3), as this was shown to be more efficient than an alternative plug flow system (Scheme 1) when evaluated on iodobenzene (2).

The "tube-in-tube" gas-liquid unit was attached to a commercial flow system; Vapourtec R2+ Series along with an R4 heating unit. Having established the reactor design, we next used 2-chloro-1-iodobenzene (4) as a model substrate for screening and identification of a set of general reaction conditions (Scheme 2). Initially, a fixed $5 \mathrm{~mol} \%$ of $\mathrm{Pd}(\mathrm{OAc})_{2}$ and $10 \mathrm{~mol} \%$ of the phosphine ligand was investigated. It was

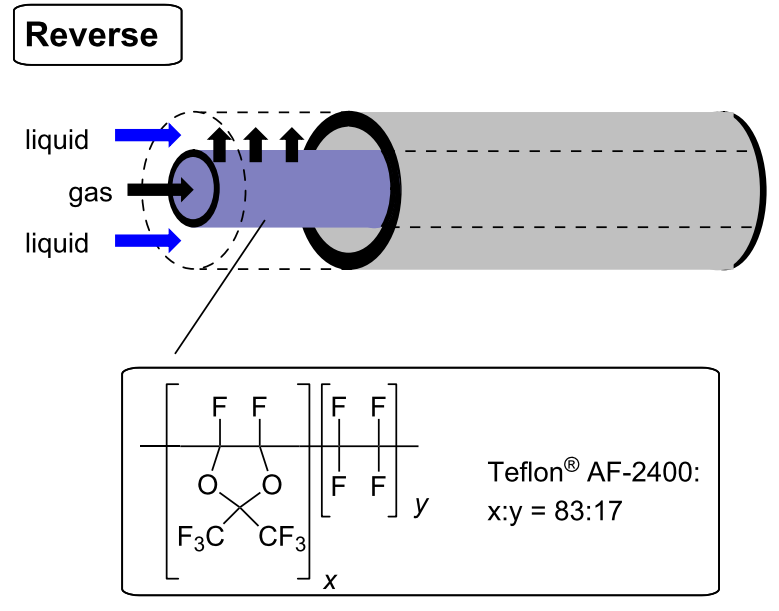

Figure 3: Reverse "tube-in-tube" reactor.

noted that the catalyst level could be reduced [34], but this amount allowed for an efficient catalytic process with short reaction times in the region of two hours, a good match for the flow system assembly [8]. Five different phosphine ligands were subsequently tested, three of which were monodentate with a variable cone angle $\left(6-8 ; 145-256^{\circ}\right)[35,36]$ and the other two bidendate phosphine ligands namely 1,4-bis(diphenylphosphino)butane (DPPB, 9; $\beta \mathrm{n}=98^{\circ}$ ) and Xantphos $\left(\mathbf{1 0} ; 104\right.$ and $133^{\circ}$ ) with differing bite angles (Figure 4) [37-39].

Initially using 5 bar of carbon monoxide and a temperature of $110^{\circ} \mathrm{C}$, the five ligands gave similar yields, with DPPB (9) giving marginally the highest and X-Phos (7) the lowest isolat-

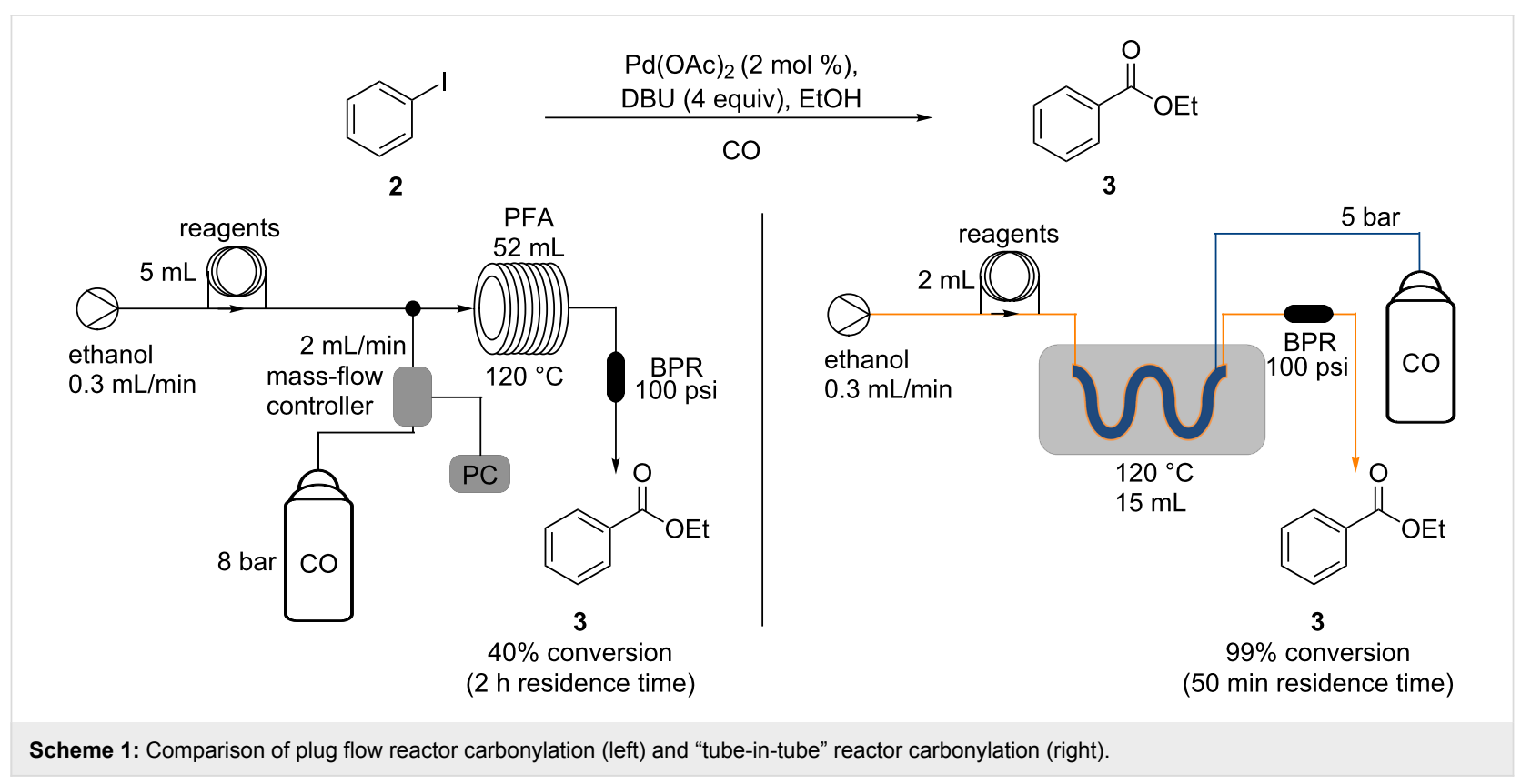




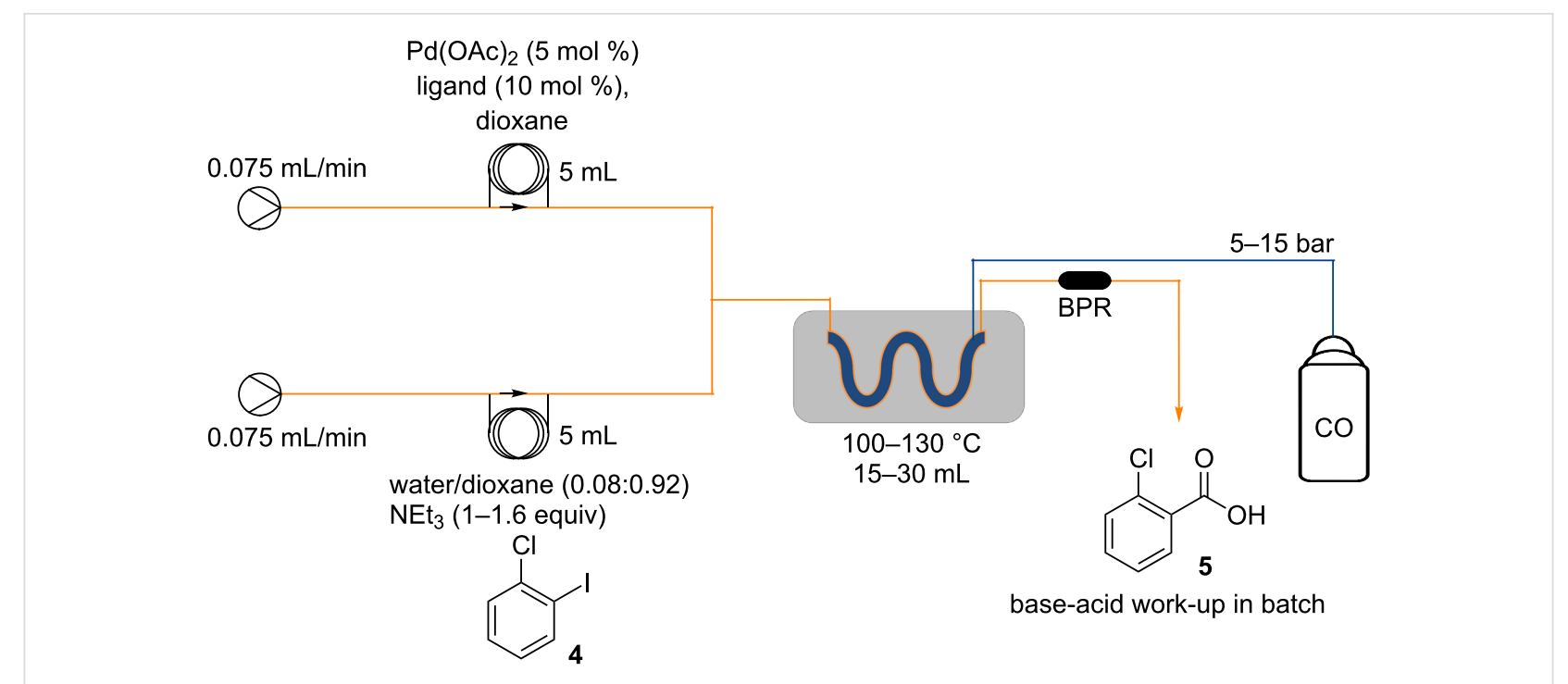

Scheme 2: Schematic diagram of the flow process.<smiles>c1ccc(P(c2ccccc2)c2ccccc2)cc1</smiles>

triphenylphosphine, 6 cone angle: $145^{\circ}$<smiles>CC(C)c1cc(C(C)C)c(-c2ccccc2P(C)(=O)c2ccccc2)c(C(C)C)c1</smiles>

X-Phos, 7 cone angle: $256^{\circ}$<smiles>COc1cccc(OC)c1-c1ccccc1OCCO</smiles>

S-Phos, 8 cone angle: $240^{\circ}$<smiles>c1ccc(P(CCCCP(c2ccccc2)c2ccccc2)c2ccccc2)cc1</smiles>

DPPB, 9 bite angle: $98^{\circ}$<smiles>CC1(C)c2cccc(Pc3ccccc3)c2OC2C(Pc3ccccc3)=CC=CC21</smiles>

Xantphos, 10 bite angle: 97 and $133^{\circ}$

Figure 4: Phosphine ligands used for the ortho-carbonylation reaction.

ed yield. However, the highest selectivities for the desired product were obtained with S-Phos (8) and triphenylphosphine (6) (Table 1, entries 2 and 5), with the difference between the conversion and the isolated yield mainly equating to the dehalogenated product namely, chlorobenzene.

Next changing the amount of triethylamine used from 1.1 equiv to 1.6 equiv and 2.0 equiv, respectively, did not significantly change the isolated yield of $\mathbf{5}$. However, changing to the stronger base $\mathrm{DBU}\left(\mathrm{p} K_{\mathrm{a}}\right.$ in water at $\left.25^{\circ} \mathrm{C}=13.5\right)$ [40] dramatically reduced the isolated yield (Table 1 , entry 8 ). A wider temperature range was also investigated (Table 1, entries 9-11). This resulted in only a small increase in the yield on going from $100{ }^{\circ} \mathrm{C}$ to $120^{\circ} \mathrm{C}$ and a marginal decrease when the temperature was further increased to $130^{\circ} \mathrm{C}$. As there was no significant difference between $110^{\circ} \mathrm{C}$ and $120^{\circ} \mathrm{C}$ (Table 1 , entries 5 and 10), the lower temperature was selected for the use in the next set of experiments. Interestingly the addition of up to $20 \mathrm{~mol} \%$ of dimethylformamide (DMF) as an additive did not improve the yield which had been suggested by evaluation of similar reactions in the literature $[6,10]$. However as anticipated, an increase in carbon monoxide pressure did pertain to a raise in product yield to $62 \%$ (Table 1, entries 12 and 13). In addition the effect of gas contact time was evaluated by employing two "tube-in-tube" reactors linked in series; albeit this resulted in only a modest improvement in yield (Table 1, entry 15). A further increase in product yield was observed when a larger excess of the triethylamine base (1.6 equiv) was used (Table 1, entry 16), but the isolated yield dropped with further equivalents of triethylamine (2.0 equiv; Table 1, entry 17). This indicated that the reaction was being inhibited by low $\mathrm{pH}$ which was generated at higher conversions when insufficient base was present to neutralise the carboxylic acid being formed. Interestingly, the requirement for a higher excess of base during initial screening (Table 1, entries 6 and 7) had been masked due to the initial low conversions achieved.

For comparison purposes, two batch carbonylation reactions were performed. The first of these batch reactions (conducted in a conventional laboratory set-up) used the palladium triphenyl- 
Table 1: Optimisation for the carbonylation of ortho-substituted substrates in flow.

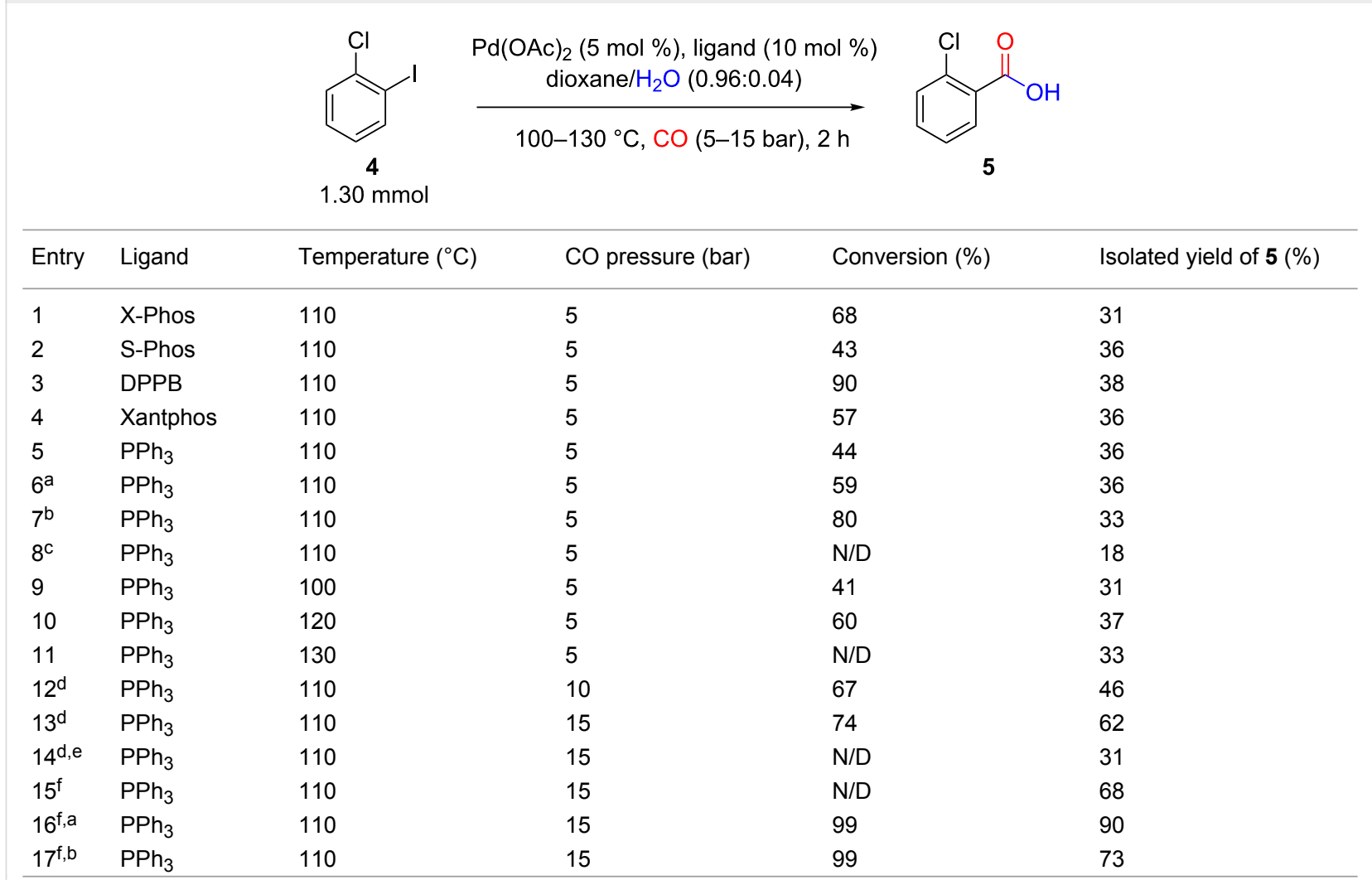

$a_{1} .6$ equiv of base. ${ }^{b} 2.0$ equiv of base. ${ }^{c} 1.1$ equiv of DBU used instead of $\mathrm{NEt}_{3} .{ }^{\mathrm{d}_{1}} 10 \mathrm{~mL}$ reactor was not "tube-in-tube". ${ }^{2} 20 \mathrm{~mol} \%$ DMF added. $\mathrm{f}_{2} \times 15 \mathrm{~mL}$ "tube-in-tube" reactors used. N/D: not determined.

phosphine catalyst system under refluxing conditions with a double-walled balloon to deliver the carbon monoxide (Scheme 3 ). This would constitute a normal set-up used by many laboratory chemists when reactions involving gases are attempted if no specialised equipment is available. Two parallel reactions were preformed, one reaction was quenched after 2 hours and after purification yielded $5 \%$ of product 5 , while the second reaction was quenched after $24 \mathrm{~h}$ yielding $9 \%$ of purified 5. The difference in the yields obtained in batch when compared to the reactions conducted in flow, most probably arises from the fact that not enough carbon monoxide is being delivered to the reaction mixture. The dehalogenation pathway is then preferred yielding chlorobenzene as the main product.

The second batch reaction set-up, conducted in the departmental high pressure lab (HPL), was set up in a Parr autoclave using carbon monoxide at 15 bar and $110{ }^{\circ} \mathrm{C}$ for 2 hours. After<smiles>Clc1ccccc1I</smiles>

4<smiles>Clc1ccccc1I</smiles>

4

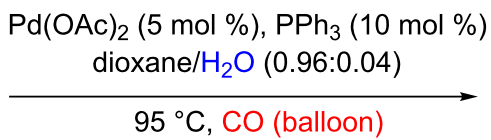

$\mathrm{Pd}(\mathrm{OAc})_{2}(5 \mathrm{~mol} \%), \mathrm{PPh}_{3}(10 \mathrm{~mol} \%)$ dioxane $/ \mathrm{H}_{2} \mathrm{O}(0.96: 0.04)$ $110^{\circ} \mathrm{C}, \mathrm{CO}(15$ bar $)$<smiles>O=C(O)c1ccccc1Cl</smiles>

5, batch yield: $2 \mathrm{~h}=5 \%, 24 \mathrm{~h}=9 \%$<smiles>O=C(O)c1ccccc1Cl</smiles>

5, batch yield: $\mathrm{HPL} \sim 2 \mathrm{~h}=87 \%$ 
purification, a yield of $87 \%$ for product 5 was obtained. This compares well with the flow protocol, however, the reaction "processing" time is in reality much longer due to the long cooling and heating times (4 h 15 min "processing" time, see experimental section in Supporting Information File 1 for more details). Also, the time required due to the extra precautionary measures needed when high pressure laboratory equipment is used means that the turnaround time is much longer. This makes the flow reactor more efficient in terms of processing time. Additionally, the added safety and potential benefits regarding scale up associated with the flow reactor makes this even more favourable.

Having identified a set of reaction conditions for successful carbonylation, a number of additional substrates were assessed to determine the generality of the flow process. No significant impact was seen on the overall yield by altering the ortho-sub- stituent to a bromo, fluoro or trifluoromethyl group. However, a slight decrease associated with the larger sizes of bromo and trifluoromethyl groups may be inferred (Scheme 4, 11, 13). A more pronounced decrease in yield was obtained for substrates 14 and 15 (Scheme 4, 63\% and 60\%, respectively) probably due to the larger size of these groups and as well as electronic effects (the more electron withdrawing trifluoromethyl group substrate 13 gave a $71 \%$ yield). For comparisons of the sizes of the ortho-substituents used, A-values can be used as a guide (Cl: $0.43 \mathrm{kcal} / \mathrm{mol}, \mathrm{Br}: 0.38 \mathrm{kcal} / \mathrm{mol}, \mathrm{F}: 0.15 \mathrm{kcal} / \mathrm{mol}$, OMe: $0.60 \mathrm{kcal} / \mathrm{mol}, \mathrm{CF}_{3}: 2.10 \mathrm{kcal} / \mathrm{mol}$ and $\mathrm{Me}: 1.70 \mathrm{kcal} / \mathrm{mol}$ ) [41]. This indicates interplay between electronic and steric factors.

Using a pyridine as a heteroaromatic substrate gave a lower but still acceptable yield of $\mathbf{1 6}$ compared to the phenyl equivalent (5). In general, substitution at the 4-position of the aryl gave moderate to good yields (Scheme 4, 17-21) with weakly elec-<smiles>[R]c1ccc(I)c([X])c1</smiles>

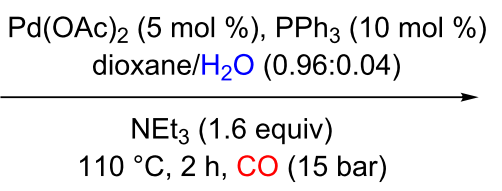

$\mathrm{X}=$ ortho-substituent $\left(\mathrm{Cl}, \mathrm{Br}, \mathrm{F}, \mathrm{CF}_{3}, \mathrm{OMe}\right.$ or $\left.\mathrm{Me}\right)$<smiles>[X]C1=C(C(=O)O)C=C[R]C=C1</smiles>

19 examples (16-90\% isolated yields) $1.30 \mathrm{mmol}$ scale<smiles>O=C(O)c1ccccc1Cl</smiles>

$5,90 \%$<smiles>O=C(O)c1ccccc1Br</smiles>

$11,70 \%$<smiles>O=C(O)c1ccccc1F</smiles>

$12,84 \%$<smiles>O=C(O)c1ccccc1C(F)(F)F</smiles>

13, $71 \%$<smiles>COc1ccccc1C(=O)O</smiles>

$14,63 \%$<smiles>Cc1ccccc1C(=O)O</smiles>

$15,60 \%$<smiles>O=C(O)c1cccnc1Cl</smiles>

$16,57 \%$<smiles>O=C(O)c1ccc(Br)cc1Cl</smiles>
$17,76 \%$<smiles>O=C(O)c1ccc(C(F)(F)F)cc1Cl</smiles>

$18,44 \%$<smiles>Cc1ccc(C(=O)O)c(Cl)c1</smiles>

$19,69 \%$<smiles>O=C(O)c1ccc(F)cc1Cl</smiles>

$20,89 \%$<smiles>O=C(O)c1ccc(Cl)cc1Cl</smiles>

$21,69 \%$<smiles>O=C(O)c1cccc2ccccc12</smiles>

22, $43 \%$<smiles>CC(C)(C)[13CH3]</smiles><smiles>[Z10][Z10]#[Z10]</smiles><smiles>O=Cc1cc(C(=O)O)ccc1Br</smiles><smiles>O=Cc1cc(C(=O)O)ccc1F</smiles><smiles>[R16][Z16]c1ccc(Br)c(C(=O)O)c1</smiles><smiles>CCOC(=O)[C@@H]1C[C@](C)(C(=O)O[R16](C)(C)C)[C@H](c2ccc(Br)c(C(=O)O)c2)N1C(=O)CC(C)C</smiles><smiles>COc1cccc(OC)c1C(=O)O</smiles>

29, $16 \%$<smiles>Cc1cccc(Cl)c1C(=O)O</smiles>

30, $12 \%$ 
tron-withdrawing substituents or electron-donating groups giving better yields (Scheme 4, compounds 17, 19-21) than the more electron-withdrawing $\mathrm{CF}_{3}$ group (Scheme 4, compound 18). In the case of 22 the attached aromatic ring introduces both the ortho substituted sterics and the electronic effects from the additional aromatic ring attached. For comparison 2-iodonaphthalene (31) was carboxylated under the same conditions to give 2-naphthoic acid (32) showing that reducing the steric encumbrance at the ortho position improves the yield by $10 \%$ for this substrate (Scheme 5).

Moderate yields were obtained with 5-substited substrates (Scheme 4, compounds 23-30). Both electron-withdrawing groups (Scheme 4, compounds 23-26) and electron-donating groups gave similar yields (Scheme 4, compounds $\mathbf{2 7}$ and 28) indicating that the inductive effects are not affecting the yields. Comparing the yields obtained for $\mathbf{2 7}$ and $\mathbf{2 8}$ also indicates that the sterics at the 5-position are not affecting the yield with a large group at the 5-position of substrate 30 [42] (see X-ray structure of substrate 33, Figure 5) actually leading to a better yield than obtained for product 27 which contains the smaller ethoxy group at the 5-position.

The lowest yields of the array were obtained for compounds 29 and 30, demonstrating the importance of sterics and electronics adjacent to the leaving group. In both cases, the carbon monoxide insertion is assumed to be slow as both axial positions of the aryl complex would be hindered, meaning the competing proton-dehalogenation pathway becomes preferred, giving 1,3dimethoxybenzene as the main product, which was isolated in $31 \%$ yield in the case of $\mathbf{2 9}$ and 3-chlorotoluene in the case of 30 which was isolated in 52\% yield (Scheme 4).

To demonstrate the potential scalability of the reaction conditions, the synthesis of compound $\mathbf{2 0}$ was repeated at $16 \mathrm{mmol}$ scale, a factor of twelve times the original $1.3 \mathrm{mmol}$ test scale (Scheme 6). The yield obtained for the larger scale was $85 \%$ which is consistent with the original $89 \%$ obtained at the $1.30 \mathrm{mmol}$ scale, indicating that the processes is robust and reliably delivering $1.19 \mathrm{~g} \mathrm{~h}^{-1}$ of $\mathbf{2 0}$ in $85 \%$ isolated yield.

\section{Conclusion}

We have successfully demonstrated how flow chemistry can be used to enhance difficult transformations such as the palladiumcatalysed hydroxy-carbonylation of ortho-substituted iodoarenes. The optimised conditions were also demonstrated to work on a number of ortho-substituted substrates giving moderate to good yields. Comparison of $\mathbf{2 2}$ with $\mathbf{3 2}$ also showed that the steric encumbrance on the ortho position has an effect on the yield even when other electronic effects are in place such as those coming from the additional aromatic ring attached. A scale-up of the reaction conditions was performed providing comparable yields to those obtained from the initial smaller test scale. This method could thus be an efficient and scalable approach to synthesising important intermediates containing ortho-substituted carboxylic acids.

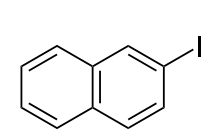

31

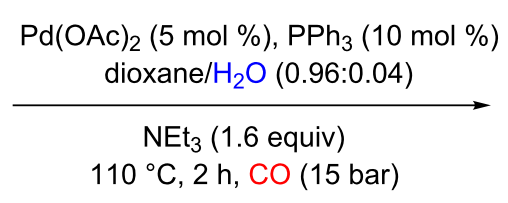

$\mathrm{NEt}_{3}$ (1.6 equiv)

(110 $\left.{ }^{\circ} \mathrm{C}, 2 \mathrm{~h}, \mathrm{CO}\right)$

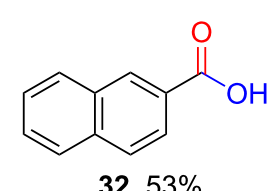

$1.30 \mathrm{mmol}$ scale

Scheme 5: Flow carbonylation of 2-iodonaphtalene.

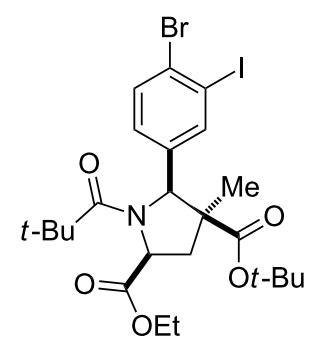

33

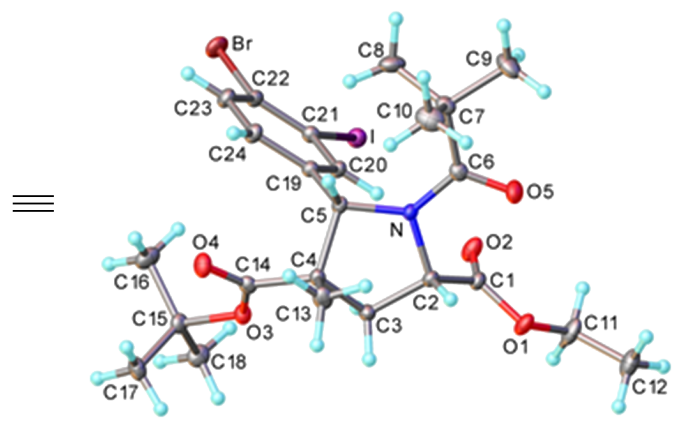

X-ray structure 


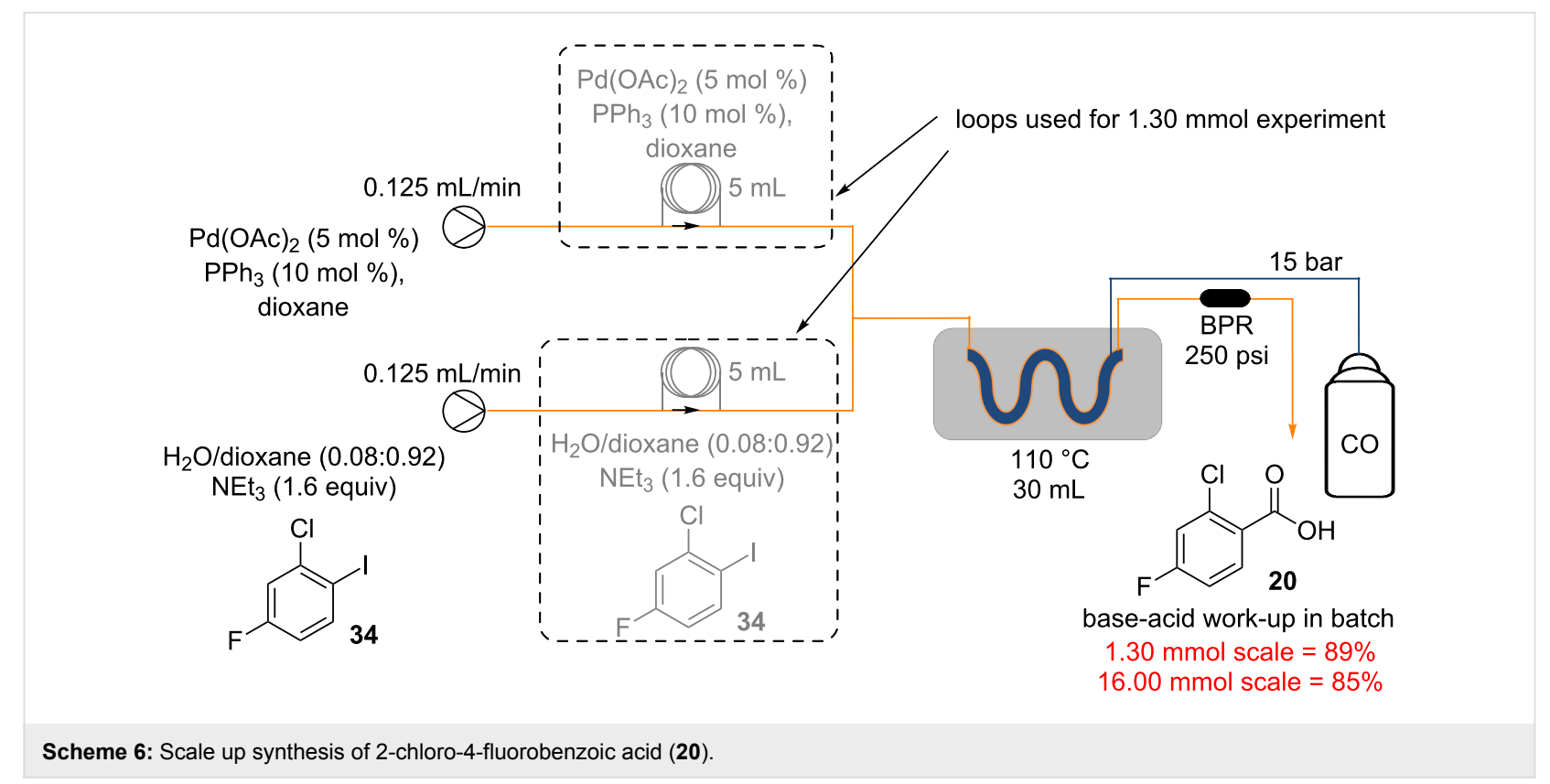

\section{Experimental}

See Supporting Information File 1 for full experimental data.

\section{General notes \\ Warning}

Carbon monoxide is highly toxic and extremely flammable gas. All reactions were carried out in well ventilated fume cupboards and carbon monoxide detectors were continuously used thought the process. High pressure lab facilities were used under the supervision of dedicated staff and all associated safety measures were taken. Parr autoclave was pressure tested at 80 bar before use.

\section{Supporting Information}

\section{Supporting Information File 1}

Experimental part.

[http://www.beilstein-journals.org/bjoc/content/

supplementary/1860-5397-12-147-S1.pdf]

\section{Supporting Information File 2}

$\mathrm{X}$-ray information data of compound $\mathbf{3 3}$.

[http://www.beilstein-journals.org/bjoc/content/

supplementary/1860-5397-12-147-S2.cif]

\section{Acknowledgements}

We would like to acknowledge the funding and support from the Royal Society (to I.R.B.; UF130576) and EPSRC/Syngenta (to C.J.M.; Grant No. EPSRC 000228396) that has enabled this work to be undertaken. Furthermore, we are grateful to Dr A.
Batsanov (Durham University, Department of Chemistry) for solving the X-ray structure.

\section{References}

1. Miller, P. W.; Long, N. J.; de Mello, A. J.; Vilar, R.; Passchier, J.; Gee, A. Chem. Commun. 2006, 546-548. doi:10.1039/B515710B

2. Rahman, M. T.; Fukuyama, T.; Kamata, N.; Sato, M.; Ryu, I. Chem. Commun. 2006, 2236-2238. doi:10.1039/b600970k

3. Miller, P. W.; Long, N. J.; de Mello, A. J.; Vilar, R.; Audrain, H.; Bender, D.; Passchier, J.; Gee, A. Angew. Chem., Int. Ed. 2007, 46, 2875-2878. doi:10.1002/anie.200604541

4. Miller, P. W.; Jennings, L. E.; deMello, A. J.; Gee, A. D.; Long, N. J.; Vilar, R. Adv. Synth. Catal. 2009, 351, 3260-3268. doi:10.1002/adsc.200900563

5. Gong, X.; Miller, P. W.; Gee, A. D.; Long, N. J.; de Mello, A. J.; Vilar, R. Chem. - Eur. J. 2012, 18, 2768-2772. doi:10.1002/chem.201104059

6. Koos, P.; Gross, U.; Polyzos, A.; O'Brien, M.; Baxendale, I.; Ley, S. V. Org. Biomol. Chem. 2011, 9, 6903-6908. doi:10.1039/c1ob06017a

7. Mercadante, M. A.; Leadbeater, N. E. Org. Biomol. Chem. 2011, 9, 6575-6578. doi:10.1039/c1ob05808h

8. Brancour, C.; Fukuyama, T.; Mukai, Y.; Skrydstrup, T.; Ryu, I. Org. Lett. 2013, 15, 2794-2797. doi:10.1021/ol401092a

9. Fukuyama, T.; Mukai, Y.; Ryu, I. Beilstein J. Org. Chem. 2011, 7, 1288-1293. doi:10.3762/bjoc.7.149

10. Gross, U.; Koos, P.; O'Brien, M.; Polyzos, A.; Ley, S. V. Eur. J. Org. Chem. 2014, 6418-6430. doi:10.1002/ejoc.201402804

11. Brennführer, A.; Neumann, H.; Beller, M. Angew. Chem., Int. Ed. 2009, 48, 4114-4133. doi:10.1002/anie.200900013

12. Wu, X.-F.; Neumann, H.; Beller, M. Chem. Rev. 2013, 113, 1-35. doi:10.1021/cr300100s

13. Brennführer, A.; Neumann, H.; Beller, M. ChemCatChem 2009, 1, 28-41. doi:10.1002/cctc.200900062

14. Grigg, R.; Mutton, S. P. Tetrahedron 2010, 66, 5515-5548. doi:10.1016/j.tet.2010.03.090 
15. Barnard, C. F. J. Org. Process Res. Dev. 2008, 12, 566-574. doi:10.1021/op800069w

16. Daniewski, A. R.; Liu, W.; Püntener, K.; Scalone, M. Org. Process Res. Dev. 2002, 6, 220-224. doi:10.1021/op0102363

17. Ashfield, L.; Barnard, C. F. J. Org. Process Res. Dev. 2007, 11, 39-43. doi:10.1021/op060193w

18. Cross, R. J.; Kennedy, A. R.; Muir, K. W. Acta Crystallogr., Sect. C: Cryst. Struct. Commun. 1995, 51, 208-210. doi:10.1107/S0108270194009042

19. Baumann, M.; Baxendale, I. R. Beilstein J. Org. Chem. 2015, 11, 1194-1219. doi:10.3762/bjoc.11.134

20. Pinho, V. D.; Gutmann, B.; Miranda, L. S. M.; de Souza, R. O. M. A.; Kappe, C. O. J. Org. Chem. 2014, 79, 1555-1562. doi:10.1021/j0402849z

21. Baxendale, I. R.; Brocken, L.; Mallia, C. J. Green Process. Synth. 2013, 2, 211-230. doi:10.1515/gps-2013-0029

22. McQuade, D. T.; Seeberger, P. H. J. Org. Chem. 2013, 78, 6384-6389. doi:10.1021/jo400583m

23. Baxendale, I. R. J. Chem. Technol. Biotechnol. 2013, 88, 519-552. doi:10.1002/jctb.4012

24. Pastre, J. C.; Browne, D. L.; O'Brien, M.; Ley, S. V. Org. Process Res. Dev. 2013, 17, 1183-1191. doi:10.1021/op400152r

25. Wiles, C.; Watts, P. Green Chem. 2012, 14, 38-54. doi:10.1039/C1GC16022B

26. Anderson, N. G. Org. Process Res. Dev. 2012, 16, 852-869. doi:10.1021/op200347k

27. Wegner, J.; Ceylan, S.; Kirschning, A. Adv. Synth. Catal. 2012, 354, 17-57. doi:10.1002/adsc.201100584

28. Malet-Sanz, L.; Susanne, F. J. Med. Chem. 2012, 55, 4062-4098. doi:10.1021/jm2006029

29. Wegner, J.; Ceylan, S.; Kirschning, A. Chem. Commun. 2011, 47, 4583-4592. doi:10.1039/c0cc05060a

30. Yue, J.; Chen, G.; Yuan, Q.; Luo, L.; Gonthier, Y. Chem. Eng. Sci. 2007, 62, 2096-2108. doi:10.1016/j.ces.2006.12.057

31. Brzozowski, M.; O'Brien, M.; Ley, S. V.; Polyzos, A. Acc. Chem. Res. 2015, 48, 349-362. doi:10.1021/ar500359m

32. O'Brien, M.; Baxendale, I. R.; Ley, S. V. Org. Lett. 2010, 12, 1596-1598. doi:10.1021/ol100322t

33. Yang, L.; Jensen, K. F. Org. Process Res. Dev. 2013, 17, 927-933. doi:10.1021/op400085a

34. Fukuyama, T.; Totoki, T.; Ryu, I. Green Chem. 2014, 16, 2042-2050. doi:10.1039/c3gc41789a

35. Immirzi, A.; Musco, A. Inorg. Chim. Acta 1977, 25, L41-L42. doi:10.1016/S0020-1693(00)95635-4

36. Clavier, H.; Nolan, S. P. Chem. Commun. 2010, 46, 841-861. doi:10.1039/b922984a

37. van Leeuwen, P. W. N. M.; Kamer, P. C. J.; Reek, J. N. H.; Dierkes, P. Chem. Rev. 2000, 100, 2741-2769. doi:10.1021/cr9902704

38. Kamer, P. C. J.; van Leeuwen, P. W. N. M.; Reek, J. N. H. Acc. Chem. Res. 2001, 34, 895-904. doi:10.1021/ar000060+

39. van der Veen, L. A.; Keeven, P. H.; Schoemaker, G. C.; Reek, J. N. H.; Kamer, P. C. J.; van Leeuwen, P. W. N. M.; Lutz, M.; Spek, A. L. Organometallics 2000, 19, 872-883. doi:10.1021/om990734o

40. Kaupmees, K.; Trummal, A.; Leito, I. Croat. Chem. Acta 2014, 87, 385-395. doi:10.5562/cca2472

41. Eliel, E. L.; Wilen, S. H.; Mander, L. N. Stereochemistry of organic compounds; Wiley \& Sons: New York, 1994.

42. Baumann, M.; Baxendale, I. R.; Kuratli, C.; Ley, S. V.; Martin, R. E.; Schneider, J. ACS Comb. Sci. 2011, 13, 405-413. doi:10.1021/co2000357

\section{License and Terms}

This is an Open Access article under the terms of the Creative Commons Attribution License

(http://creativecommons.org/licenses/by/2.0), which permits unrestricted use, distribution, and reproduction in any medium, provided the original work is properly cited.

The license is subject to the Beilstein Journal of Organic Chemistry terms and conditions:

(http://www.beilstein-journals.org/bjoc)

The definitive version of this article is the electronic one which can be found at:

doi:10.3762/bjoc. 12.147 